\title{
Perspectives on Corruption and Contemporary Anti-Corruption Policies in Nigeria: A Critique*
}

\author{
Dr. Benjamin O. Igwenyi \\ Associate Professor, Department of Public and Private Law, Ebonyi State University, \\ PMB O53,Abakaliki, Nigeria
}

\begin{abstract}
Corruption which is an anti- social concept is the use of one's position wherever located to earn underserved benefits for oneself or for others. Its effects are devastating to the growth of the individual, society and the country at large. Corruption as an aspect of crime is traceable to so many factors. According to bio-physiological theorists, there are born criminals who are known and could be identified by their physical features just like the psychological theorists contend that the character traits of the individual is responsible for his criminal activities. On the other hand, socio-cultural theorists contend that it is the surrounding circumstances in the environment of the individual that makes him to be involved in crime. Just as demonological theorists believe that the devil makes people to commit sin. The above theories have their usefulness in the understanding of the causes of corruption in the society. The socio-cultural theorists however appear to have most of the factors responsible for corruption in Nigeria such as the nature of our political economy, poverty, lack of essential amenities, fears of the unknown, wrong value system, attitude to public service job, unemployment, poor reward system and etc. The government in her bid to combat corruption has enacted some anti-corruption legislations such as the E.F.C.C and I.C.P.C Acts, the Criminal Code and introduced some palliatives that would help to avoid corruption for persons in the public and private sectors of the economy but the problem of corruption continues to be. This paper intends to critically look at the above issues and proffer solutions on how to eradicate or reduce corruption in Nigeria.
\end{abstract}

Keywords: Corruption, crimes, origins, causes, panacea, strategies.

DOI: $10.7176 / \mathrm{JLPG} / 89-12$

Publication date:September $30^{\text {th }} 2019$

\subsection{Introduction}

Corruption is an anti-social behaviour which is predicated on the use of one's official or unofficial position to gain some benefits inconsistent with one's position and against the interest of other members of the society. It is demonstrated in all aspects of our national life, and people get involved in it both consciously and unconsciously. We say this because, the police man who asks for money for "pure water" on the road and the driver who gives the money always feel that it is a normal thing for such to happen without knowing that it is an act of corruption. The same thing occurs when a clerk or civil servant demands for "money for break" during official hours from members of the public who come for one transaction or the other. Its prevalence is reported in the radio, televisions, social media, newspapers and magazines, (Adebayo 2019, Nwosu 2017, Folashadekoyi 2016,).

The effect of corruption in Nigeria is unquantifiable because it has led to national stagnation in all spheres of national life, be it public or private sector. Corruption was responsible for the first Military Coup in Nigeria, (January 15, 1966) and all other

Military Coups in Nigeria were all traceable to corruption though those who come to fight corruption normally end up being more corrupt,(Abacha 1993).

Though, this paper is on Perspectives on Corruption and Contemporary Anti-Corruption Policies, we shall make brief remark on the meaning of corruption, its classification, and theories of origin to enable us have full grasp of the issues in contention before delving into our main topic. We shall then conclude by making our recommendations as to the way forward in the fight against corruption in Nigeria.

\subsection{Corruption, Classification and Theories of Origin.}

\subsubsection{What is Corruption}

Corruption as a crime is difficult to define and its difficulty is recognized by scholars. According to R. Seidman, "Corruption, like law, truth and beauty has no agreed definition",(Seidman 1974). The reason for the divergent opinion about corruption is because it covers wide area of human activity and people approach its definition from how they feel about it, hence the concept is fluid. However, we must make attempt to pick some definitions. According to Concise Oxford English Dictionary "corruption is derived from corrupt and to be corrupt, means willing to act dishonestly in return for money or personal gain", (Soanes and Stevenson 2004). The Black's Law Dictionary, defines it as the act of doing something with an intent to give some advantage inconsistent with official duty and the rights of others; a fiduciary's or official's use of a station or office to procure some benefit either personally or for someone else, contrary to the right of others (Garner 2004). A seasoned academic, 
Gunar Mydral, simply defined corruption, as "a term used to include all forms of improper or selfish exercise of power and influence, attached to a public as well as a private office", (Mydral, 1997).

Hence, without taking us into further definitions, we can summarize that all forms of the use of one's position, be you a President, Governor, Public or Civil Servant of any grade, workman, trader and even motor drivers to get underserved benefits for themselves or another person is an act of corruption. It cuts across tangible and intangible benefits. It is not limited to bribery or stealing, or padding of contracts, but cuts across all forms of use of one's position to take what one does not deserve ordinarily. This will cover armed robbery, stealing, kidnapping, pipeline vandalism, over invoicing of prices of goods and services by service providers, rigging of elections, examination malpractices, obtaining by false pretences and etc. So, it can be seen in all aspects of our lives and to be fair to Nigeria, it is a global issue that every person has to be concerned about. The only difference is that in Nigeria, the institutions that ought to fight corruption are very weak unlike what obtains in the developed countries of the world where institutions are strong and performing well.

\subsubsection{Classification of Corruption}

Scholars have attempted to group or classify corruption depending on the area of its preponderance. Thus, we have political corruption, bureaucratic corruption, economic corruption and moral corruption.

\subsection{2. (a) Political Corruption}

Political Corruption is a term used to define all forms of misuse of a public position of trust and its meaning and application vary with time, place and culture. It covers all actions taken to get undue political advantage over other political parties or associations such as vote buying, vote rigging, political assassination, manipulation of the country's Constitution or Laws in order to gain advantage over other persons.

\subsection{2. (b) Bureaucratic Corruption}

This is the type of corruption which takes place within the bureaucracy. Bureaucracy has been defined as a system of government in which most decisions are taken by

State officials rather than by elected representatives. Here, officialdom, which is complicated dominates and corruption takes place where officials in the system take bribe, before they carry out their functions. For example, when in 2006, the former President, Chief Olusegu Obasanjo, and his Vice President, Alhaji Atiku Abubakar were involved in taking money from Petroleum Technology Development Fund (PTDF), it was classified as political corruption, (Johnson 2006). So, when Ministers, Directors, Commissioners, Civil Servants of all grades are involved in all manner of cheating before they take decisions or actions, these fall under bureaucratic corruption, and this is where most people look at corruption, forgetting the private sector.

\subsection{2. (c ) Economic Corruption}

On the other hand, as the name suggests, it refers to all those unethical and unlawful acts of persons and or institutions, which adversely affect the economy. These will include pipeline vandalism, unlawful bunkering of the country's oil, bribery by multinational companies, import and export frauds, stock market manipulations, questionable privatization of companies, advance fee fraud, and other forms of financial crimes. It also involves adulteration of goods and services by persons and institutions involved in production of goods etc.

1.2.2. (d) Judicial corruption is located in the Judiciary, which is made up of court clerks, bailiffs, registrars, magistrates, judges and other para-judicial staff. Thus, when these officials act unethically in the discharge of their duties this is classified as judicial corruption. In the past few days, the newspapers have been covered with news of some justices of Superior Courts in Nigeria, who were arrested with millions of naira and thousands of other currencies in their houses and some of them are already charged to Court, (Folashadekoyi 2016).

\subsection{2.(e)Moral Corruption}

Morality and Law are not the same thing, but often, they merge. Morality deals with principles concerning right or wrong, or good and bad, while law deals with any conduct that is prohibited and carrying penal sanctions. Thus, when a moral issue is accompanied with legal obligation, it becomes binding on the individual. Having said this, moral corruption has been located in sexual immorality, lying, drunkenness, indiscipline of all types and none adherence to religious and moral institutions, (Igwenyi 2010). Thus, when protocol officers in government arrange for young school girls to be imported from schools for state functions, it is moral corruption. In the same vein, when top government officials travel with their 'conference bags' (girls), it is moral corruption; when manufacturers produce or traffic in fake products, it is moral corruption; we can also classify human trafficking or child trafficking, killing human beings for rituals, examinational malpractices and false claims by men of God, of performing one miracle or the other as aspects of moral corruption.

\subsubsection{Theories of Origin of Corruption}

It is apposite to say that the origins of corruption, sometimes may overlap on the causes of corruption, but we shall try to separate the two. The following are views canvassed by scholars as to the origin of corruption, that is to say, how corruption started, or when it started.

\subsubsection{Theological Explanation}

If we accept that corruption is the use of one's position, whether private or public to get what one is not entitled to ordinarily, it can be said authoritatively that the first act of corruption took place in the Holy Bible and that 
was when Adam and Eve, notwithstanding the injunction given to them by God, not to eat the forbidden fruit proceeded to disobey Him and ate the fruit of the tree of knowledge, (Genesis 3: 1-7). The same story is rendered in the Holy Koran chapter 2: 36-37 where it was written: "and he said 'O Adam, dwell thou and thy wife in the garden, and eat therefrom plentifully wherever you will, but approach not this tree, lest you be of the wrongdoers. But Satan caused them both to slip by means of it and drove them out of the state in which they were..." By using their position in the Garden of Eden and going for the fruit of knowledge which now made them more knowledgeable in the negative sense, they became corrupt and fell out of God's favour and were driven out of the garden. This is the theological explanation of the origin of corruption and we agree with that. Thus, we can say that this act of disobedience of God, which made the man and woman to know that they were now naked was the origin of corruption and other crimes.

Also in the Holy Bible, there were so many other instances of corrupt acts. First, it was reported in Genesis $6: 1-4$, that sons of God had illicit relationship with daughters of men, and this infuriated God, and that made him to reduce the life span of man to 120 years. God even regretted creating man, (Genesis 6: 5-7). In the same vein, the illicit life style of sons of Eli (Chief Priest) that is Hophini and Phinehas, who specialized in forcible confiscation of proceeds of sacrifice to God, and laying with women who came for sacrifice, come within what we are saying. The refusal of king Saul of Israel to destroy the Amalekites, and their king Agag, and the their property, is an act of corruption on the part of king Saul, $\left(\mathbf{1}^{\text {st }}\right.$ Samuel 15:1-10). The same can be said also of the atrocities of king Ahab and Queen Jezebel; the problems of king David over Uriah who he later took the wife after killing him, $\left(2^{\text {nd }}\right.$ Samuel chaps 11and 12). Coming to the New Testament, there were also glaring cases of corruption. The first was the allegation of bribing of Judas Iscariot by Jewish authorities in order to betray his master, Jesus Christ, (Mathew chaps 26: 14-16; 48-50). In the same breathe, Jewish authorities bribed soldiers guarding the tomb of Jesus Christ to lie that Jesus did not rise from death but was removed by his Disciples, (Mathew 28:12-15). We also have in Acts of Apostles: 5:1-11, of the case of Ananias and Sapphira, where the duo, lied to the brethren in order to save money for themselves. Hence, we can say that corruption came with man.

\subsubsection{Explanation Based On Ancient Practices}

Another explanation as to the origin of corruption is that it arose from the practices of ancient societies. According to this school of thought, led by Felix Pomeranz, corruption arose because "in ancient societies, man had a religiously rooted reverence for his social superiors to whom he felt he ought to bring propitiating 'gifts', as he did to gods, spirits and demons". To this school of thought, the blessing of civilization has dismantled this traditional network, replacing it with acts, now branded corruption due to bureaucracy. In other words, corruption arose from the age long gift-giving culture of ancient societies whereby inferiors gave gifts to their superiors as show of reverence. But this theory has been debunked because the gift giving culture of the ancient societies was based on appreciation that was done in the open, unlike the current situation, where such gifts are done in the secrets which makes them corrupt gifts.

\subsubsection{Marxist Explanation}

Another explanation is the one given by the Marxists school of thought. According to this school of thought, which is based on the principle of "scientific socialism" and "dialectical materialism": "the roots of corruption should not be sought in the values and attitudes of individuals in the society, in other words, in the assumed nature of man, nor explained away simply as part and parcel of the social norms, values and practices of developed societies, rather it should be sought in the nature of the social system prevalent in a particular society". This school believes that the motive force of history in all that man does is economic and that the mode of production, distribution and exchange of goods and services is the determining factor in man's relationship with one another.

According to Marxists, a social system which encourages profit motive and materialism will lead to corruption, while that which discourages profit motive, will not create ground for corruption. In summary, the Marxists believe that a country that practices capitalism, which emphasizes individualism, profit motive, primitive accumulation, will be corrupt, and that corruption arose from capitalism. It is however, arguable whether there is no corruption in countries that practise Socialism and Marxism as the case may be. So to this school corruption originated from capitalism.

\subsubsection{Theory of Two Publics:}

Another theory on the origin of corruption is the theory of "two publics", which was propounded by Peter Ekeh. According to this theory, colonial rule in Nigeria created a situation where one and the same individual belongs to "two publics": the primordial public and civic public. The primordial public is constituted by the categorical identities of ethnicity and religion which is in the private realm, while the civic public is the public realm of the official bureaucracy, that is public service in general. According to Ekeh, political corruption, gathers strength in Africa, and has expanded its scope, because it is widely accepted, that the use of civic public office and funds for the benefit of one's primordial grouping is legitimate, (Ekeh 1998). In other words, colonialism and the colonial civil service should be blamed for corruption as government property and money 
are seen as 'whiteman's money' which one is free to take. The irony of it, is that if somebody steals money from the primordial public, he is ostracized by members of that group and cursed, but not otherwise, if he steals money from the civic public and brings home. Thus, the public service is seen as a foreign authority and to cheat it is legitimate.

\subsubsection{Explanation Based On African Culture}

There is also the view that corruption is traceable to Africa culture which is the practice of giving gift to visitors and friends. This act of giving gifts to visitors and friends according to them has expanded in scope and led to the current state of affairs of bribery and corruption in the society. However, afro-centric writers have debunked this view contending that the gift -giving culture of Africans is positive and done in the open and remains positive aspect of African culture. This cannot be compared to outright inflation of contracts, award of phoney contracts, leaking of official secrets for monetary gains, political assassinations etc, that constitute corruption in our modern society. So, if there is an abuse of African gift- giving culture, it should not be traced to the culture of Africans.

\subsubsection{Fear of The Unknown}

There is also another view by Bishop Peter Akinola (Rtd), of the Anglican Commission, that corruption in Nigeria is traceable to mass purge in the public service which took place in Nigeria in the 1970s. This purge led to the throwing out of so many public servants and those who remained, no longer feel safe and adopt any measure to cheat while in the service, (Akinola n.d)

\subsubsection{Transfer Effect}

Finally, there is also the contention that corruption in Nigeria is traceable to "transfer effects" of anti-colonial activities of Nigerians before independence in 1960, (Nwankwo 2001). According to Arthur Nwankwo, during the struggle for impendence, Nigerians were encouraged to disobey the colonial government in all respects and that after the grant of independence, Nigerians transferred the bad behaviour to the government of the new Nigeria. Some of these include not coming to work or lateness to work, tax evasion etc which are corrupt acts etc. We can therefore, see that there are varied views on the origin of corruption and none of them can be dismissed as they are all relevant in the discussion of the subject matter.

\subsubsection{Perspectives on Corruption}

In the above segment, we treated cultural theories as regards the origin of corruption. Herein, we shall deal with the main subject, which is why are people involved in the crime of corruption, that is to say, the etymology of crime. It should be noted that this is entirely in the area of criminology, but we shall make attempt to do some justice to the topic. But it is important to note that under "the multi-factor theory" that the causation of crime is attributable to several factors. That being the case, scholars have identified the following schools of thought as those who have tried to give explanation as to why people commit crime in the society. They are the Biophysiological theorists, the psychological theorists, the socio-cultural theorists, and the demonological theorists.

\subsection{4 (a) Bio-physiological Theory:}

The people who belong to this school of thought contend that crime is attributable to the biological and physiological indices in the human person. To this school of thought, persons who have certain physical features are prone to crime. The first thinker who is noted for this view is Cesare Lombroso (1835-1909), an Italian physician and Lecturer at the University of Turin. His ideas are contained in his work titled: L' Uomo Delinquent (the Criminal Man), which was published in 1876. He was said to have integrated Auguste Comte's positivism and Charles Darwin's evolutionism, and other pioneering studies on the relation of crime to the body, to propose scientifically that criminals are lower form of life, nearer to their ape-like ancestors, than non-criminals in traits and dispositions, (Williams 1991). To him, criminals are distinguished from non-criminals by various "atavistic stigmata"- physical features of creatures at an earlier stage of development before they became fully human. He contended that criminals frequently have huge jaws and strong canine teeth, characteristics common to carnivores, who tear and devour meat raw. The arms span of criminals is often greater than their height, just like that of apes, who use their forearms to propel themselves along the ground. To him, an individual born with any five of the stigmata is "a born criminal" (Adler 1995).

Though the theory of Lombroso was criticized for not answering certain questions with regards to why some people who have the 'atavistic stigmata' were not involved in crime, his findings helped the Italian government of his time to focus more on the individuals in the formulation of polices on justice administration. His efforts also led to the emergence of classical criminologists, who improved on his ideas. Thus, Raffaele Garofalo (1852-1934), Italian Professor of Law, former Senator and Magistrate now opined that criminal behaviours cannot be traced to physical features of individuals, but their psychological equivalent which he called "moral anomalies". Thus, to him, the causation of crime in the society is attributable to the internal workings of the body organs of human person. In other words, people commit crimes because of factors beyond their control, and not because of their free will to do so-a sort of delving into psychology. 


\subsection{4. (b) Psychological Theory}

The psychological theorists are those thinkers who attribute propensity to commit crime to the psychological or character traits of the individuals. This school of thought, contends that people commit crime because of what happen in their thought processes which are complex. They, however, agree that internal factors in a person may be affected positively or negatively by the environment, (Williams 1991). Notable scholars in this field include Sigmund Freud (1856-1939), and Lawrence Kohlberg.

\subsection{4. (c) Socio-Cultural Theory}

This school of thought contends that people commit crime in the society because of the condition they find themselves in. This is a very broad area because of the involvement of behavioural scientists such as sociologists, political scientists, economists, anthropologists, etc, whose ideas overlap in attempt to find the causes of crime.

The first scholar that attract our attention here is a French sociologist, Emile Durkhein (1858-1917) who propounded 'the strain theory', whereof he argued that as the society advances through urbanization, the State gets into the state of "anomie", whereof, there is breakdown of socio-order as a result of loss of standards and values. Implicit in this theory, is that criminal behaviour is caused by urbanization, which makes the society no longer cohesive for the purpose of behavioural control.

Another group within this school of thought is the socialists, represented by Karl Marx (1818-1883). According to Karl Marx and his group, it is the socio-economic conditions in the society that determine the relationship between the various classes of people in that society. It is not the consciousness of men that determines their beings, but on the contrary, their social being determines their consciousness. In other words, people commit crimes because of their socio- economic conditions, which they have no control over. The Marxists, as followers of Karl Marx were known and are still known, used historical materialism and dialectical materialism to explain the relationship between the various components of the society in terms of why things happen the way they do.

\subsection{4. (d) The Demonological Theory.}

Perhaps, another explanation of the cause of crime, is the one attributable to the 'demons' or the 'evil spirit' or 'the other world' or 'world powers' which is one of the earliest perspectives on causation of crime. Though the English man appears to over look it, to avoid being superstitious, from Biblical account of what happened in the Garden of Eden, it cannot be wished away that the devil can cause a person to be involved in criminal behaviour. Whether we believe it or not, whether consciously or unconsciously, we always refer to the devil as causing our criminal behaviour, whether Christian or Muslim, (Tsa 2005). So, if Eve in the Bible (Genesis 3:1-13) attributed her disobedience to God to the deception by the devil, which led to the fall of man, and the sufferings we are undergoing in the society today, we should not throw away the influence of demons in the causation of crime.

Conclusively, on theories of causation of the crime of corruption in Nigeria, we can see that each of the schools of thoughts have one point or the other to make in the reason why corruption is prevalent in Nigeria. First, looking at the socio-cultural theorists, we find so many explanations, such as that people are corrupt in Nigeria because of the nature of our political economy, which is capitalism, which encourages individualism, primitive acquisition and other negative features. People are also corrupt because of pervasive property which can be located in the social-cultural theory also. Lack of essential amenities in the key sectors of the economy, such as health, education, agriculture, transport etc. also breed corruption. The same is true of fear of the unknown by public office holders, who want to make it while in office before retirement. Wrong value system amongst our people, is also a factor in the escalation of the crime of corruption, as our people worship money, rather than good character.

The attitude of our people to public service job and property is another factor in the causation of crime of corruption, as our people see public service job as the white man's job. Another factor, which is socio-cultural in the causation of the crime of corruption in Nigeria, is poor salaries of public servants, which make them perpetual beggars. Another factor is poor treatment meted out to retired civil and public servants whose pensions and gratuities are hardly paid when they retire. Another factor in the escalation of the crime of corruption in Nigeria, is weak governmental institutions such as the Nigeria police force, the judiciary, the ICPC and EFCC. These agencies appear not to be independent as they are used by whoever is the President, to pursue his interests instead of national interests.

Corruption is also given encouragement in Nigeria, because some foreign governments and foreign financial institutions create opportunities for looters of our money to keep their stolen funds in foreign banks. It is also important to mention that greed and avarice, are also factors in the escalation of corruption in Nigeria, otherwise, why would former Governors, or Ministers or Commissioners be still involved in the act of graft if not because of their psychological deficiencies.

We have taken time to mention in outline the above factors because they will help us to make our recommendations on the way out of corruption. 


\subsection{Contemporary Anti-Corruption Policies in Nigeria \\ 1.3.1 Laws Against Corruption}

In discussing contemporary anti-corruption polices in Nigeria, it is important to mention that the war against corruption in Nigeria had been mainly fought with laws which include the Criminal Code of Act, (LFN, 2010) the Penal Code Law, (LNN, 1963) the Economic and Financial Crimes Commission Act, $($ LFN, 2010) the Corrupt Practices and Other Related Offences Act, (LFN, 2010) the Money Laundering Act, (LFN, 2010) the Failed Banks (Recovery of Debts) and Financial Malpractices in Bank Act, (LFN, 2010) to mention but these.

The Criminal Code, which is the oldest of all the legislations has been with us since 1916 with few amendments, and has sections dealing specifically with the crime of corruption. These are sections 98, 98A, 98B, 99 and 112, which prescribe various punishments with maximum sentence of seven years for various acts of corruption. The Criminal Code which operates in the Southern States of Nigeria has been used to try and punish people for acts of corruption, yet, the crime is still on the rise.

The Penal Code, which operates in the Northern part of Nigeria in sections 115-122, provides punishment for different acts of corruption. Many have been tried and convicted under this law, but the complexity of the act of corruption appears to have made nonsense of these laws, hence the need for new laws.

On the $13^{\text {th }}$ of June, 2000, Chief Olusegun Obasanjo, the former President of Nigeria, signed into law the Corrupt Practices and Other Offences Commission Act, which had intention of blocking all the loopholes in the Criminal Code, and the Penal Code. Sections 8,9,10,12,13,15,16,17,18,19,20 and 21 etc made provisions that prohibit all aspects of corruption, particularly in the Public Service. Not contented with the enactment of the ICPC Act, President Obasanjo in the year 2002 promulgated and signed into law the Economic and Financial Crime Commission Act. This law was made to help in fighting not only economic crimes in Nigeria, but also trans- border crimes. It should be noted that this law came in reaction to the September 11, 2001, terrorists attack in New York, which led to the death of over three thousand Americans. So far, the fear of EFCC in Nigeria is now the beginning of wisdom as many politicians, big business men, public servants and ordinary persons have been thrown into Prisons because of the effort of the EFCC, which appears to be more efficient than other anticorruption agencies in the country.

It is important to note that the Code of Conduct for Public Officers, (Nigeria 1999) has also provisions which are aimed at ensuring transparency in governance, and prohibit corruption. A person convicted for breach of code of conduct, under paragraph 18 sub 7, is not entitled to prerogative of mercy.

Notwithstanding the above laws prohibiting and punishing corruption, the offence appears to be escalating. It would appear that the laws have failed us in our fight against corruption and there is the need to change tactics.

\subsubsection{Use of Special Tribunals}

Apart from the above conventional laws that have been used in Nigeria to fight corruption, special tribunals have been used by the various governments to recover ill-gotten wealth from our past politicians and public office holders. The first major effort was the enactment of the Public Officers (Investigation of Assets) Decree,(1966). This decree, empowered the Head of State to require public officers to declare their assets and competent persons were appointed to verify such declarations. This decree made provision for tribunal of inquiry to investigate public officers suspected of corruption. Under this decree, many public office holders and their collaborators had their properties confisticated. That was under the Ironsi-Gowon regime, which led to the popular case of Lakanmi \& Ors v. Attorney General of Western Region, (1971).

The Murtala-Obasanjo regime enacted the Corrupt Practices Decree, (Nigeria 1975). The decree prohibited acts of corruption against official bodies. It was under this regime that the 1979 Constitution was conceived which made provision for Code of Conduct for Public Officers, which prohibits certain criminal and unethical behaviours in the public service.

The Shehu Shagaris's regime inherited the 1979 Constitution and went further to launch Ethical Revolution, all aimed at fighting corruption. On $31^{\text {st }}$ December, 1983, General Mohammadu Buhari came into power via military coup, and introduced many radical changes in the war against corruption, and launched War Against Indiscipline. That regime enacted Recovery of Public Property (Special Military Tribunals) Decree, 1984, which made outlandish provisions against corruption. Many former Governors, Ministers, and their collaborators, were sentenced to several years of imprisonment by the Special Military Tribunals.

The Ibrahim Babangida's government, 1985 to 1993, also made feeble effort at fighting corruption and ended up being more corrupt than the civilian government the army replaced in 1983. General Sani Abacha, who came in on $17^{\text {th }}$ November, 1993 and who died in June 1998 left the scene worst than he met it. On $1^{\text {st }}$ October 1999, Chief Olusegun Obasanjo, came back as a civilian leader and this is where we are.

\subsubsection{Adoption of People- Oriented Economic Polices}

The Government of the Country has under several regimes in Nigeria, tried to adopt people- oriented economic policies, aimed at empowering people so that they can avoid corruption. Very noticeable is the issue of loans to occupational groups as well as co-operative societies. During the General Sani Abacha regime, 1993-1998, there was the Family Economic Advancement Programme (FEAP), which did not make the required impact. There 
was also the Obasanjo National Poverty Eradication Programme (NAPEP), whereof, some unemployed citizens were paid N7, 500 per month. We also have the National Directorate of Employment, that is (NDE Scheme), where some unemployed Nigerians get self employed. All these measures are aimed at fighting corruption.

\subsubsection{Public Service Reforms.}

In the bid to fight corruption in Nigeria, the federal government has embarked on measures to improve the welfare of workers, and ensure transparency in public service. Thus, between 1999 and date, the salary of civil servants and public officers have been greatly improved upon. There are new pension laws aimed at making sure that the civil servant enjoys his retirement. We also have fiscal responsibility measures, aimed at ensuring accountability. We also have Due Process Mechanism, all aimed at reducing corruption. Only recently, the federal government introduced Treasury Single Account (TSA), aimed at preventing graft, in the collection and remission of government revenues. This is the much we can take in the discussion of contemporary anticorruption measures. We shall now turn our attention to the way forward.

\subsection{Conclusion and Recommendations}

In the preceding part of this work, we have tried to explain the concept of corruption, its origin, theories of its causation and some anti-corruption measures that have been tried by various governments in Nigeria. We would want to say that the panacea to the problem of corruption in Nigeria, is to first address the issues identified, as the causes of corruption, as this is the only way of tackling the problem. Consequently, we hereby propose the following as what we consider practical measures to fight and defeat corruption in Nigeria.

1. Free and fair elections: We contend that if elections in Nigeria are not neatly organized and good men of honour are elected into government, there will be no end to corruption. Thus, if a bad man becomes Governor or President or Local Government Chairman, he will only appoint people like himself, and the circle of corruption will continue. This is because other political players, contractors, and public servants will all be bad people that 'helped' the president or governor to come to power. So no free and fair elections, no end to corruption.

2. Strict Enforcement of the Existing Laws: It is not in doubt, that Nigeria has more than enough laws to fight corruption but their implementation. So, if the EFCC, ICPC Acts, and the Code of Conduct for Public Officers are religiously enforced, corruption will be brought to its knees. Thus, apart from imprisonment of the convict, all the proceeds of corruption, be they houses, cars, money in banks, etc should all be recovered from any person convicted of corruption. In other words, it is our contention that plea bargaining should not be encouraged as it has the tendency of still allowing the convict to keep part of his loot.

3. Anti-Corruption Tribunal: Cases involving corruption should be expeditiously tried and disposed off so that the people will appreciate the seriousness of the crime and seriousness of government action. To this end, a special Court should be created which will be dedicated for trial of cases of corruption and there should be a division of this court in every State of the Federation. This will hasten the trial of matters concerning corruption in the country, instead of the current situation, where the regular courts sit over same for several years because of the number of cases they are contending with. Some scholars have argued that the performance of election tribunals in the country as special courts (because of corruption allegation against some of the judges) does not support this suggestion. However, the reason for our suggestion is not to stop corruption in the judiciary but to hasten the trial of cases of corruption and avoid undue delay which we observe in the regular courts. Afterall, the regular courts also have problem of corruption for those judges who compromise their positions. The courts being suggested will not be emergency courts as election tribunals which normally generate a lot of political attention and the attendant tendency to influence the membership.

4. Change Of Our Political Economy: Though this suggestion may offend so many people who 'have made it', it is our contention that corruption cannot be fought to a standstill in Nigeria if we continue to practice raw capitalism with its very many negative features, such as primitive acquisition of property, excessive individualism and undue profit motive. In other words, we are advising that the government of Nigeria tries socialism to reduce the tendency of people pursuing money at all cost. Hence, there should be a limit to the number of houses, cars, and cash a person should be entitled to and not to allow persons to continue to be rich and rich to the detriment of the masses.

5. Citizenship Education: It is our suggestion that corruption should be taught as a course in our primary and secondary schools at the formative stage of Nigerians, so that they will know the harm it is causing to the people and government of Nigeria. Here, the students should be made to know that the colonial masters are gone and that the property now in the country belongs to Nigerians and not the white man. It is our view, therefore, that if Nigerians are educated on what corruption is all about and its consequences, children will start fighting against corruption before getting to adulthood.

6. Whistle Blowers: In the civilized societies, those who report acts of corruption are protected and paid. 
We therefore, recommend that the Nigerian government should make law that will provide suitable ground for whistle blowers to be paid commission from the proceeds of recovered loots based on their information. They should also be protected by the government. We are therefore happy that the Nigerian National Assembly is putting finishing touches on the law which will make official the use of Whistle Blowers in Nigeria. We are not unmindful of the recent attempt by government to pay some money to informants but we are saying that there should be formal law on this issue.

7. Anti-Corruption Agencies to be Independent: The War against Corruption in Nigeria, cannot work if the anti-corruption agencies only act when directed by the man at helm of affairs. So, the ICPC, the EFCC, the Nigeria Police, the judiciary should be strengthened, to be independent of undue control by the presidency. It is no longer news that the presidency, in most cases dictates who should be charged, and who should not be charged, either by the police, DSS, ICPC or EFCC. This does not help in the fight against corruption in the country.

8. Private Sector to be Brought in, in the Fight Against Corruption: To fight corruption in Nigeria, some of the existing laws should be amended to include private sector as area where corruption takes place and where it should also be fought. Most often, the search light is on the public institutions and corruption is allowed to hold sway in the private sector. Thus, the role of market men and women in price modulation and cheating, the role of National Union of Road Transport Workers in hiking transport fares, manipulation of bill of quantities by government contractors and etc cannot be controlled if the private sector is allowed without legislations.

Finally, staff welfare in the Public Service. It is our contention that if public servants are paid living wages, they will do their work with dedication and commitment. A situation where the N18, 000 (Eighteen Thousand Naira monthly) minimum wage cannot pay house rent, school fees and feeding for a family, can only expose such person to intensive corruption. So, we are saying that a hungry man can easily be a corrupt man, because he must eat with his family members. So, salaries of workers should be improved upon to discourage them from being corrupt.

It is also our suggestion that the Code of Conduct for Public Officers in Nigeria, (Nigeria, 1999) should be amended to allow public servants to engage in private practice of their

profession when not on duty. A situation where a public servant is only allowed to be engaged in farming as private practice is not helping in the fight against corruption as the public servant is prevented from making more money for himself thereby making him vulnerable to corruption in his public service job.

Conclusively, the war against corruption should be a comprehensive effort because we have tomorrow to protect. If we fail to manage the economy very well for the good of all, the country and all the citizens will be the victims of the malady.

\section{References}

Adler F., et al,(1995), Criminology, 2nd Edn, Mc Graw Hill; Inc., New York: pp.60-63.

Adebayo M. (2019), "SERAP Backs EFCC's Probe of Obasanjo Government's \$16 Billion Power Project", Daily Sun, Monday 19, August 2019, p.10. website:www.sunnewsonline.com.

Akinola P.,(n.d) Greed: Mother of Indiscipline and Corruption, Ehindero Nig. Ltd, Jos:, P.15.

Ekeh P.,(1998), "Colonialism and the Two Publics in Africa: A theoretical Statement" in Peter Lawis (ed.), Africa, Dilemmas of Change and Development, West View Press, London. P. 87.

Folashadekoyi (2016), "I Didn't Give Justice Ajumoghobia N5m Bribe - Obla" the Daily Sun, Wednesday, November 9, 2016. Pp. 8 and 13. Folasadekoyi,(2016), "DSS Raids: NJC Bars Judges from Accepting Gifts," The Sun, October 24, 2016, Pg.8;

Folasadekoyi,(2016), “Arms Scandals: Panel Submits Final Report, Indicts Top FG Officials”. New Telegraph, October 27, 2016, P.2,

Garner B.A, (2004), Black's Law Dictionary, (8 ${ }^{\text {th }}$ edn.) West Publishing Co., Dallas Texas: P.371

Igwenyi B.O., (2010), The Crime of Corruption in Nigeria: Laws, Issues and Solutions, Snaap Press, Enugu, Pp. 1-34, 41-44.

Johnson,(2006), “Aso Rock of Corruption”, The News, September 25, 2006. Pp. 18-21

Mydral G., (1997), Corruption as Hindrance to Modernization in South Asia (New Brunswick: Transaction Publishers, P. 405. Mydral G. is a Professor of Law.

Nwankwo A., (2001), "Political Economy of Corruption in Nigeria" in C. Akani (ed.) Corruption in Nigeria: The Nigeria Delta Experience, $4^{\text {th }}$ Dimension Publishers Ltd, Enugu: page 9.

Nwosu (2017), "Malabu Oil: I am Not Part of Deal - Jonathan”, Daily Sun, Wednesday January 11, 2017, Page 9.

Nigeria (1999), Paragraph 2 of Part 1,5 th Schedule to the 1999 Constitution of Nigeria (as amended) which prohibits private practice of one's profession if one is a public officer save farming.

Seidman R.,(1974) "Corruption: A case Study in Deviance” in Paul Brietzke, Source Book of Ethiopian Law and 
Development, 1974 P. 262 cited by I.A. Ayua: "Overview of Corruption in Nigeria” in I.A. Ayua and B. Owasanoye (eds.) Problems of Corruption in Nigeria (Lagos: NIALS, 2001), P.4.

Soanes C and Stevenson A., (2004), Concise Oxford English Dictionary, Oxford University Press, New York: pp. 321-322.

Tsa G.,(2005), “Tafa Balogun Jailed Over Corruption”, Daily Sun, Thursday, November 24, 2005, P.4.

Williams,(1991), Textbook on Criminology, Blackstone Press Ltd, London:p.93.

Genesis 3: 1-7.

Genesis 6:5-7.

$1^{\text {st }}$ Samuel 15:1-10.

$2^{\text {nd }}$ Samuel 11: and 12.

Mathew 26: 14-16, 48 -50.

Mathew 28: 12-15.

Criminal Code, (Chapter) Cap C.38 Laws of the Federation of Nigeria, (LFN) 2010.

Corrupt Practices and Other Related Offences Act, Cap C31 LFN, 2010.

Economic and Financial Crimes Act, Cap E1 LFN, 2010.

Money Laundering (Prohibition) Act Cap M18, LFN, 2010.

Penal Code, Cap 105 Laws of Northern Nigeria, 1963. 